\title{
PROBLEMS OF REFORMING UKRAINIAN FAMILY LAW IN THE CONTEXT OF EUROPEAN INTEGRATION AND RECODIFICATION OF THE CIVIL CODE OF UKRAINE
}

\section{Mendzhul M. V.}

\section{INTRODUCTION}

After execution of the Association Agreement with the European Union, Ukraine has committed to adjust its national legislation in accordance with the rules of the European Union. Therefore, one of the areas of reform - namely family law - is expecting its reform in order to comply with European standards. Moreover, as a result of the European integration of UKraine, the process of modernization of the Civil Code of Ukraine has been launched through its recodification. In this research we have analyzed the impact of the recodification of the Civil Code of Ukraine and the processes of unification of the European principles of family law on improving the Family Code of Ukraine.

\section{Recodification of the Civil Code of Ukraine and the development of family law}

Five years ago scholars mostly justified the need to modernize the Civil Code of Ukraine. At the moment they have intensified research on the problems of its recodification. This is confirmed by a series of recent articles by leading Ukraine scholars and presentations on the problems of recodification at the panel discussion ("Updating the Civil Law of Ukraine: Towards a Europeanization of Private Law") with the participation of not only scholars but also judges of the Constitutional Court of Ukraine and the Supreme Court. ${ }^{1}$

The question is what is recodification? In his research, Muzyka L. A. drew attention to the fact that foreign scholars use the term "codification"

\footnotetext{
${ }^{1}$ На III Харківському міжнародному юридичному форумі обговорили оновлення цивільного законодавства та необхідність європеїзації приватного права. URL: https://legalforum.nlu.edu.ua/news/na-iii-kharkivskomu-mizhnarodnomu-iurydychnomuforumi-obhovoryly-onovlennia-tsyvilnoho-zakonodavstva-ta-neobkhidnist-ievropeizatsiipryvatnoho-prava/.
} 
to use "recodification", and the latter means both "re-codification" and "reverse" of codification. ${ }^{2}$ In particular, such a term was used in the scientific article by Hondius E.H. back in $1982 .{ }^{3}$ Dovgert A. uses the term "recodification" to mean "systemic substantive structural and substantive innovations of the current code (or group of codes and laws), without creating a new one" ${ }^{4}$.

According to Muzyka L. A. recodification should be understood as the legislative activity that substantially alters the structure and scope of legal regulation included into the code (or the group of codes) and accounts the practice of their application. It can also be understood as changing (including amendment or removal) of the fundamental and most essential provisions in the code. And the scholar also proposes the term 'decodification', which means the legislative activity after which the Code is no more legally binding as a law. ${ }^{5}$ We agree with this position, so not every subsequent codification will be considered a recodification. In the dissertation research Sirko M.V. justifies that in the 80-s of the XX century there was actually a recodification of civil law in the European states ${ }^{6}$.

The general conclusion of the panel discussion "Renewal of the Civil Law of Ukraine: Towards a Europeanization of Private Law" is that not just the modernization of the rules of civil law is necessary, but the whole recodification of the Civil Code of Ukraine, including due to the fact that it was adopted more than 15 years ago, and some of its legal provisions do not reflect the current needs for regulating social relations. During the recodification, scholars propose to identify, which norms are effective and efficient in regulating civil relations, and which, on the contrary, need

${ }^{2}$ Музика Л. А. Що є актуальним для сучасного цивільного законодавства України: модернізація, системне оновлення чи рекодифікація? Науковий вісник Львівського державного університету внутрішніх справ. 2015. Вип. 1. С. 147.

${ }^{3}$ Hondius E.H. Recodification of the Law in the Netherlands: The New Civil Code experience. Netherlands International Law Review. Volume 29, Issue 3. December 1982, pp. 348-367.

${ }^{4}$ Довгерт Анатолій. Рекодифікація Цивільного кодексу України: основні чинники і передумови для старту. Право України. 2019. № 1: Національна доктрина приватного права: основні методологічні засади. С. 27.

${ }^{5}$ Музика Л. А. Що $є$ актуальним для сучасного цивільного законодавства України: модернізація, системне оновлення чи рекодифікація? Науковий вісник Львівського державного університету внутрішніх справ. 2015. Вип. 1. С. 149.

${ }^{6}$ Сирко М.В. Цивільний кодекс Франції 1804 року та його вплив на цивільне законодавство країн Європи (на прикладі Польщі та Румунії). Дисертація на здобуття наукового ступеня кандидата юридичних наук по спец.: 12.00.01 Львів, 2015. С. 29. 
improvement, including in accordance with European and international standards. We can agree with S. Pohribnij's conclusion that the criterion of both efficiency and effectiveness of the norms is the relevant case law ${ }^{7}$. Muzyka L. believes that the following steps should be taken in the codification of civil law: doctrine $\rightarrow$ lawmaking $\rightarrow$ practice of application $^{8}$. In our opinion, when it comes to recodification, the scheme should look in the following way: practice of application $\rightarrow$ doctrine $\rightarrow$ lawmaking. That is why the recodification process should include a thorough analysis of the practice of application of legal rules, in particular judicial practice. After such analysis it is necessary to establish at the doctrinal level the position about the effectiveness and efficiency of one set of legal rules, and accordingly about the gaps in legislation and about inefficiency of other legal rules, and the development of appropriate proposals to amend the code.

Dovgert A. notes that the process of recodification of the Civil Code of Ukraine should take place under the "European scenario", taking into account the transformation of society, the formation of an efficient market economy, which the scholar considers as a component of civil society, as well as the European integration of society ${ }^{9}$.

Illarionov O. believes that possible recodification of the Civil Code of Ukraine will lead to decodification of commercial and family law. ${ }^{10}$ We do not agree with this view and believe that the basis of recodification of the Family Code of Ukraine is precisely the European integration processes of Ukraine, as well as the need to align family law with the European principles of family law.

In the history of the development of private law of an independent Ukraine, the question of the expediency of the Family Code has already been discussed, in particular during the drafting of the Civil Code. For example, the Civil Code Working Group wanted to unite all private law into one civil code and the family law should have become an integral

${ }^{7}$ Про рекодифікацію цивільного права, медіацію та мирову угоду говорили судді КЦС ВС на юридичному форумі у Харкові. URL: https://supreme.court.gov.ua/ supreme/pres-centr/news/793713/

${ }^{8}$ Музика Л. Кодифікація та декодифікація: проблемні питання. Jurnalul juridic național: teorie și practică. Iunie 2015. C. 55.

${ }^{9}$ Довгерт Анатолій. Рекодифікація Цивільного кодексу України: основні чинники і передумови для старту. Право України. Національна доктрина приватного права: основні методологічні засади. 2019. № 1. С. 30.

10 Ілларіонов О. Рекодифікація = декодифікація? URL: https://blog.liga.net/user/ aillarionov/article/34014 
part of civil code but as a separate chapter of it. ${ }^{11}$ Romovs'ka Z.V. advocated the position that family law must be embraced in the independent code. As a result, the Civil Code of Ukraine (January 16, 2003) and the Family Code of Ukraine (a year earlier - January 10, 2002) were adopted separately, which have become legally binding on January 1, 2004. From 2004 and up to the present day, the Family Code of Ukraine has been amended by forty-six laws, most recently amended on August 28, 2018, and it was interpreted by two judgments of the Constitutional Court of Ukraine.

Undoubtedly, in the context of the recodification of the Civil Code of Ukraine, proposals for decodification the Family Code of Ukraine and including its provisions in the new Civil Code of Ukraine may be discussed. In our opinion, given the history of the development of family law on the territory of Ukraine, existing experience of codification of family law, a positive practice of applying the rules of the Family Code, its decodification would be groundless. At the same time, we are convinced that in the context of the recodification of the Civil Code, it is possible to modernize the provisions of the Family Code of Ukraine.

\section{The experience of the unification of European principles of family law}

The problem of harmonization of the private law of Ukraine in general and family law in particular with the law of the EU has been repeatedly addressed not only by scholars but also by politicians. There are works about the process of unification of European family law by European scholars (Marianne Roth, Frederik Swennen, Velina Todorova, Branka Rešetar, Milana Hrusaková, Ingrid Lund-Andersen, Anne Barlow, Nina Dethloff, Dieter Martiny and others) and Ukrainian scholars (Valentyna Borysova, Iryna Zhylinkova, Zoryslava Romovs'ka, Larysa Krasyts'ka, Ol'ha Yavor and others) ${ }^{12}$.

The very creation of the European Union implies the harmonization and approximation of the laws of the Member States. The Treaty establishing the European Community, adopted on 25 March 1957, provided for the approximation of the laws of the Member States for the

11 Ватрас В.А. Кодифікація новітнього сімейного законодавства: історія та сучасність. Університетські наукові записки, 2016. № 58, С. 36-37.

12 Менджул М. В. Перспективи уніфікації європейського сімейного права. Visegrad Journal on Human Rights. 2019. №. 3. Vol. 1. P. 186. 
functioning of the common market, which undoubtedly marked the recognition at international level of the processes of harmonization of the laws of the EU Member States.

The harmonization of family law in the EU is approved through the EU Council Regulations, the case law of the European Court of Human Rights, and the activities of the Commission on European Family Law, which has been actively developing the principles of European family law since 2001.

That is why, in our opinion, the modernization of the Family Code of Ukraine should take into account the regulations of the EU Council, the legal positions of the ECtHR, as well as the principles developed by the Commission on European Family Law. In particular, among the EU Regulations and other acts, the following should be taken into account: Council Regulation (EC) No 44/2001 of 22 December 2000 on jurisdiction and the recognition and enforcement of judgments in civil and commercial matters (Article 5 states that it applies to cases relating to alimony), Council Regulation (EC) No 2201/2003 of 27 November 2003 concerning jurisdiction and the recognition and enforcement of judgments in matrimonial matters and the matters of parental responsibility, repealing Regulation (EC) No 1347/2000, Council Regulation (EC) No 4/2009 of 18 December 2008 on jurisdiction, applicable law, recognition and enforcement of decisions and cooperation in matters relating to maintenance obligations, Council Regulation (EU) No 1259/2010 of 20 December 2010 implementing enhanced cooperation in the area of the law applicable to divorce and legal separation, Council Regulation (EU) 2016/1103 of 24 June 2016 implementing enhanced cooperation in the area of jurisdiction, applicable law and the recognition and enforcement of decisions in matters of matrimonial property regimes, Council Regulation (EU) 2016/1104 of 24 June 2016 implementing enhanced cooperation in the area of jurisdiction, applicable law and the recognition and enforcement of decisions in matters of the property consequences of registered partnerships, Recommendation of the Committee of Ministers to Member States on family mediation of 21 January 1998, Directive 2008/52/EC of the European Parliament and of the Council of 21 May 2008 on certain aspects of mediation in civil and commercial matters and others.

Article 5 of Council Regulation (EC) No 44/2001 of 22 December 2000 on jurisdiction and the recognition and enforcement of judgments in civil and commercial matters establishes the procedure for bringing a 
claim, and in particular pursuant to paragraph 2, to a person domiciled in one EU Member State may be sued in another EU Member State in an alimony case in the court of the place of residence (or habitual residence) of the person entitled to the alimony. In the event that the alimony dispute is contiguous to a dispute about the civil status of the person, the claim shall be brought before a court having the jurisdiction under national law to admit such claims, unless that jurisdiction is based solely on the nationality of one of the parties.

Council Regulation (EC) No 2201/2003 of 27 November 2003 concerning jurisdiction and the recognition and enforcement of judgments in matrimonial matters and the matters of parental responsibility was adopted in order to create in the EU an area of freedom, security and justice, guaranteeing the free movement of persons , and to ensure the equality of all children, the Regulation extends to all decisions on parental responsibilities, including measures to protect children, regardless of the existence of judicial proceedings between spouses. According to Art. 1 the Regulation shall apply to civil disputes which are the subject of divorce, the establishment of the regime of separate residence of the spouses or the invalidation of marriage, the acquisition, exercise, restriction, termination of parental duties, if they relate to disputes about: the right to cohabit with the child and upbringing and access to the child; establishment of guardianship, guardianship and similar legal institutions; the appointment of a person or body caring for the child or his property represents the interests and assistance of the child, and the determination of the relevant functions of that person or body; transfer of the child to a foster home or special institution; child protection measures related to the management, preservation or disposal of the child's property. In general, the said Regulation is based on the principles of: mutual recognition of court decisions (part 2 of the preamble), protection of the best interests of the child (part 12 of the preamble), consideration of the child's opinion (part 19-20 of the preamble, Article 23), mutual trust in recognition and execution of court decisions on family disputes (part 21 of the preamble), the most favorable placement (the principle applies in the determination of the authorized court for family disputes (Article 15), etc.

In December 2008, Council Regulation (EC) No 4/2009 of 18 December 2008 on jurisdiction, applicable law, recognition and enforcement of decisions and cooperation in matters relating to 
maintenance obligations was adopted. All the obligations to pay alimony arising from family, paternity, marriage or family relations were covered by the said Regulation in order to guarantee a unified approach. It contains uniform rules for the application of both court and administrative decisions on an impartial basis and ensuring that all parties to the case are heard (preamble, paras. 11-12).

Paragraph 19 of the preamble to Council Regulation (EC) No 4/2009 states that in order to enhance the legal certainty, predictability and autonomy of the parties, the parties to the relationship have the right to choose a competent court under a contract based on special conflict of law, and to protect the weakness of such a choice of court. should be for the benefit of children under the age of eighteen. Article 46 of the Regulation states that EU Member States must provide free legal assistance in all matters relating to child support obligations arising from a parent-child relationship, under the age of 21 years. Thus, EU Council Regulation (EC) No 4/2009 contains uniform conflict-of-law rules that determine, within the EU, which legislation must be applied to the alimony obligations, establishes uniform rules on the mutual recognition of judgments and their enforcement.

Directive 2008/52 / EC of the European Parliament and of the Council on certain aspects of mediation in civil and commercial matters of 21.05.2008 No 2008/52/EC, pursuant to Article 1, applies to cross-border civil and commercial disputes, with the exception of rights and obligations that cannot be agreed by the parties other than those provided for by applicable law, in order to facilitate access to alternative dispute resolution procedures and to facilitate the amicable settlement of disputes. Concerning mediation in family disputes, on 21 January 1998 the Committee of Ministers of the Council of Europe adopted Recommendation No. R (98) 1 at 616 meetings of the Ministers of Ministers. That act stated that the use of mediation in family matters could improve communication between family members, reduce conflict, lead to amicable settlement of disputes, ensure the duration of personal relationships between parents and children, and in this connection it is recommended that the governments of the Member States: encourage or, where necessary, enhance mediation in family matters; take or strengthen any measures necessary to comply with the principles of family mediation as a proper means of resolving family disputes.

Given that there are more than 16 million marriages with a foreign element in the EU, legal certainty on various aspects of family life is 
important. Regulation No 1259/2010 (commonly known as the Rome III Regulation) sets out the procedure for defining legislation in the event of a divorce with a foreign element, and has been applicable in 17 countries since 29 January 2019: Sweden, Belgium, Greece, Croatia, Slovenia, Spain, France, Portugal, Italy, Malta, Luxembourg, Germany, Czech Republic, Netherlands, Austria, Bulgaria and Finland ${ }^{13}$.

Council Regulation (EC) No 1259/2010 of 20.12.2010 on the extension of cooperation in the area of the law applicable to divorce and legal separation complements Regulation (EU) No 593/2008 of the European Parliament and of the Council on the law applicable to contractual matters obligations ("Rome I") "of 17.06.2008 and Regulation (EC) No 864/2007 of the European Parliament and of the Council" On the law applicable to non-contractual obligations ("Rome II") "of 11.07.2007, which identified the general trend of harmonization of EU conflict-of-law rules in the field of civil and trade relations. Scholars note that the adoption of the Rome I and Rome II Regulations completed the main principles of European private international law and played an important role in the process of unification of private international law in the $\mathrm{EU}^{14}$.

Council Regulation (EC) No 1259/2010 Rome II continued to unify conflict-of-law rules and principles applicable to private relations and contains sufficiently important rules to determine which right to apply in the event of divorce, judicial separation (spousal regime) in marital relations with a foreign element. In the Regulation analyzed, the principle of autonomy of the will was proclaimed as the basic one in dealing with conflict issues. Council Regulation (EC) No 1259/2010 "Rome II" applies only to marriage dissolution and single spousal residence regimes and does not regulate the legal capacity of individuals, the validity and recognition of marriage, the invalidity of marriage, spouses, property rights of spouses, marital property rights parental relations, alimony, property rights and inheritance (Article 1). An analysis of the provisions of Council Regulation (EC) No 1259/2010 of 20 December 2010 on the extension of cooperation in the field of law applicable to marriage

\footnotetext{
${ }^{13}$ Lhoest B., (2016). The Harmonization of European Family Law: Work in Progress. URL: https://www.peacepalacelibrary.nl/2016/12/the-harmonization-of-european-family-lawwork-in-progress/.

${ }_{14}$ Трощенко I. О. Роль Регламенту «Рим II» в уніфікації міжнародного приватного права в СС. Держава і право. Юридичні і політичні науки. Випуск 53. 2011. C. 576.
} 
dissolution and legal separation allowed to conclude that it contains uniform conflict-of-law rules in order to determine the applicable law to the relations indicated therein. The following principles can be found in the Regulation: legal certainty (paragraph 9 of the preamble), autonomy of the will and freedom of choice of spouses of the law to be enforced in divorce (paragraphs 14-16 of the preamble), informed choice of law to be applied (paragraph 18, 19 of the Preamble), prohibition of discrimination (paragraph 30 of the preamble) and others.

We agree with scholars that, following the example of Macedonia, Ukraine also needs to comply with the provisions of the Rome III Regulation, and in the Law of Ukraine "On Private International Law" to increase the number of conflicting anchorages that should be applied when marriage is terminated and the parties choose the law ${ }^{15}$.

On 24 June 2016, two EU Council Regulations No 2016/1103 implementing enhanced cooperation in the area of jurisdiction, applicable law and the recognition and enforcement of decisions in matters of matrimonial property regimes and No. 2016/1104 implementing enhanced cooperation in the area of jurisdiction, applicable law and the recognition and enforcement of decisions in matters of the property consequences of registered partnerships, which, under the transitional provisions, have fully entered into force on 29 January 2019.

Council Regulation (EC) No 2016/1103 applies to regimes of matrimonial property and does not cover matters such as: marital capacity, existence, validity or recognition of marriage; the obligation to withhold; succession to the property of the deceased spouse; social security; rights in the case of divorce, separation, or annulment of a retirement pension for years of service or a disability pension accrued at the time of marriage and which did not bring retirement income at the time of marriage; the nature of the ownership of the property; any record in the real estate or movable property registry. According to Article 5 of the Rules, where a court is considering a divorce case, establishing a spousal residence regime, annulment of marriage, then this court has jurisdiction over matters of matrimonial property regimes.

Council Regulation (EC) No 2016/1104 applies only to the property consequences of registered partnerships having a cross-border component,

${ }^{15}$ Ватрас В. А. Проблеми та перспективи кодифікації міжнародного сімейного права України. Міжнародне приватне право. C. 182-186. URL: http://www.univer.km.ua/ statti/2.vatras_v.a._problemy_ta_perspektyvy_kodyfikatsiyi_mizhnarodnoho_simeynoho_ prava_ukrayiny.pdf. 
and has been adopted to ensure that couples have legal certainty about their property, a degree of foreseeability and the definition of all rules in one document (preamble paragraph 15). That is why there was a unification of legal norms and principles regarding the regulation of property relations of registered partnerships. Moreover, according to paragraph 16 of the preamble, "to ensure the smooth functioning of the internal market, it is necessary to remove the barriers to the free movement of people who have entered into a registered partnership, especially those which make it difficult for such couples to manage and distribute their property." It is for this purpose that the Council Regulation 2016/1104 combines jurisdiction, applicable law, recognition (or adoption), applicability and enforcement of decisions, authentic documents and agreements. However, according to paragraph 17 of the preamble, a "registered partnership" is defined only for the purposes of the regulation, and the actual substance of the concept must be defined in the national legislation of the EU Member States. However, it is noted that the provisions of this Regulation do not oblige an EU Member State whose legislation does not have a registered partnership institution to provide for it in its national legislation.

Thus, both Regulations, like all other Regulations, have been adopted for the purpose of developing the sphere of freedom, security, promotion of justice and free movement of persons, and contain a number of common principles: proportionality, legal certainty; predictability; mutual recognition of court decisions; autonomy of the parties; the contractual choice of law to be applied; the unity of the applicable legislation; the benefits of a peaceful settlement of the dispute; recognition of authentic documents; respect for privacy and family life; nondiscrimination; guaranteeing the right to an effective remedy and a fair trial, etc. Regulations Nos 2016/1103 and 2016/1104, Article 21, contain the principle of unity of applicable law, according to which the law applicable to the regime of matrimonial property (partnership property) applies to all assets subject to that regime, irrespective of whether where they are located. At the same time, these Regulations have excellent bases, for example, only EU Council Regulation No 2016/1103 contains the principle of guaranteeing marriage.

It is definitely too early to talk about codification of European family law. We agree with Dieter Martini that only after the continuation of the pan-European codification of civil law is it possible to decide on the scope and form of systematization of family law. 


\section{Modernization of the family code of Ukraine in the context of European integration}

Commission on European Family Law developed: Principles of European family law regarding divorce and maintenance between former spouses $^{16}$, Principles of European family law regarding parental responsibilities ${ }^{17}$, Principles of European family law regarding property relations between spouses ${ }^{18}$, Principles of European family law regarding property, maintenance and succession rights of couples in de-facto unions. The latest guidelines were published in August $2019^{19}$.

The question is - to what extent does the Family Code of Ukraine comply with the principles of European family law?

The first CEFL divorce and retention principles were published in December $2004^{20}$. Articles 105-107, 109, 110 and 112 of the Family Code of Ukraine comply 19 with European principles (1:1 - 1:4), in particular: freedom to dissolve marriage is guaranteed by law; no specific length of marriage is required for the marriage to be dissolved; the procedure for dissolution of marriage is defined by law and is carried out by the competent authority (both through court and administrative body); both types of divorce are guaranteed (by mutual consent and without the consent of one spouse).

At the same time, the Commission on European Family Law recommended setting a period of friendly settlement: "If the couple has children under 16 and they have agreed to all the consequences of the agreement at the beginning of the divorce, a three-month period of friendly settlement is established. If they have not agreed on all the consequences, a six-month period is required. If the couple does not have children under the age of sixteen and they have agreed in the agreement all the consequences of the divorce, then the period of such settlement is not required, if they

${ }^{16}$ Principles of european family law regarding divorce and maintenance between former spouses. URL: http://ceflonline.net/wp-content/uploads/Principles-English.pdf.

${ }^{17}$ Principles of european familylaw regarding parental responsibilities. URL: http://ceflonline.net/wp-content/uploads/Principles-PR-English.pdf.

${ }^{18}$ Principles of european family law regarding property relations between spouses. URL: http://ceflonline.net/wp-content/uploads/Principles-PRS-English1.pdf.

19 Katharina Boele-Woelki, Frédérique Ferrand, Cristina González-Beilfuss, Maarit Jänterä-Jareborg, Nigel Lowe, Dieter Martiny, Velina Todorova. Principles of European Family Law Regarding Property, Maintenance and Succession Rights of Couples in de facto Unions. 2019. 282 p.

${ }^{20}$ Boele-Woelki, K., 2005. The principles of European family law: its aims and prospects. Utrecht Law Review, 1(2), pp. 164. DOI: http://doi.org/10.18352/ulr.13. 
have not agreed all the consequences - a three-month period of settlement is established. Also, a reconciliation period is not required if the marriage actually ended within six months before the divorce".

The Family Code of Ukraine in Article 111 only stipulates that the court shall take measures to reconcile the couple, if this does not contradict the moral principles of society. The period of conciliation is defined by Article 240 of the Civil Procedure Code of Ukraine, in particular, it is stated that the court may suspend the case and appoint a spouse a term for conciliation/settlement, which may not exceed six months. There is a variety of jurisprudence in Ukraine for setting time limits for reconciliation. Considering the principles developed by the Commission on European Family Law, in our opinion, it is worth the Art. 111 of the Family Code of Ukraine to be supplemented with part two with the following content: «2. If the couple has children under 16 and agreed to the consequences of the provision of Article 112-1 of this Code before the court or before the commencement of the case, then the period for conciliation is up to three months, if the spouses have not agreed on the legal consequences of the divorce. , the reconciliation period is up to six months. If the couple does not have children under the age of sixteen and they have not agreed to the legal consequences of the divorce provided for in Article 112-1, paragraphs 2 and 2, a three-month term of conciliation shall be set. A reconciliation period shall not be established if the spousal residence regime of at least six months has been established prior to divorce, as well as if the spouses do not have children under 16 and have agreed to the legal effects of divorce provided for in subparagraphs (c) and (c). h. Article 112-1, Part 2".

Although the 1:8 Principle of Divorce and Retention of the Commission on European Family Law states that divorce without the consent of one spouse should be allowed, if their relationship actually ended more than one year. Article 112 of the Family Code of Ukraine is more liberal, and involves the dissolution of marriage without any preconditions, but only on the ground that it would be established that the further cohabitation of the spouses and the preservation of the marriage would be contrary to the interests of one of them, to the interests of their children.

Chapter 9 of the Family Code of Ukraine generally complies with the principles of divorce and retention of the European Family Law Commission. However, unlike the Family Code of Ukraine, the principles of European family law do not limit the right to alimony by such a condition as the inability of one spouse to work and pay alimony. 
The CEFL principles establish that in determining the alimony in favor of one of the former spouses, the following must be taken into account: the need for one of the spouses in the maintenance and the ability of the other former spouse to provide such maintenance; ability, age and health; performing childcare by one of the spouses; distribution of responsibilities during marriage; duration of marriage; standard of living during marriage; the presence of a new marriage or long-term relationship. In our opinion, the family law of Ukraine should be supplemented by the missing criteria.

European Family Law Principles on Parental Obligations of the European Family Law Commission aims to ensure the well-being of the child, and in this connection, Art. 7 of the Family Code of Ukraine should be supplemented by such a general principle as the welfare of the child. In addition, the family law of Ukraine should be supplemented by the principles of the autonomy of the child (according to which the right of the child to act independently in accordance with the level of development of its abilities and taking into account needs), protection of the interests of the child in the conflict of his interests with the interests of the parents (children should not be discriminated against on grounds such as gender, race, skin color, language, religion, political or other beliefs, national, ethnic or social background, sexual orientation, disability, property status, istse birth, etc.).

In order to align family law with the principle of 3:21, Article 160 of the Family Code of Ukraine must be supplemented by the rule that: "The parent of the child with whom the child resides must inform the other of the parent in advance about the change of the place of residence of the child. In the event of a dispute about the change of the child's place of residence, each parent may apply to a guardianship or court authority”. The second paragraph of Part 1 of Art. 161 of the Family Code of Ukraine redrafted in the following way: "In resolving the dispute over the place of residence of the minor child the following circumstances are taken into account: the attitude of the parents to the fulfillment of their parental responsibilities, the personal commitment of the child to each of them, the child's age, the child's opinion, his state of health, parent's living conditions, geographical distance and remoteness, other significant circumstances".

In order to comply with the Principle 3:22 Article 177 of the Family Code of Ukraine, the second sentence of paragraph 1 must be redrafted in the following way: "Parents are obliged with due care secure saving 
and increase the value of the property of the child, use it in the best interests of a child”. The provision of Article 178 of the Family code of Ukraine on the use of the income from the property of the child is in line with European principles of family law.

The family law of Ukraine is in line with the European principles of family law to guarantee the right of the child to contact his parents and other relatives (principles 3:25 - 3:28), as well as to deprive and restore parental rights.

However, the Family Code of Ukraine does not contain rules on alternative dispute resolution (eg mediation), with the principle of 3:36 establishing an alternative dispute resolution (in all disputes concerning parental responsibilities, alternative dispute resolution mechanisms should be available). A similar norm should be provided in the family law of Ukraine.

In addition, the principle of 3:38 "Appointing a Special Representative for a Child" is important, and in our view, it should also be enshrined in family law, namely: a conflict of interest between the child and the parents, or the risk of the child's well-being, the court appoints a special representative for the child".

The family law of Ukraine is in line with such European principles of family law as equality, recognition of full legal capacity for each spouse, participation of each spouse in meeting the needs of the family according to his (her) abilities (includes not only financial contribution, but also housekeeping, raising children), concluding a contract on family property with the consent of another spouse, freedom to conclude contracts between spouses on their property, etc.

At the same time, the legislation of Ukraine does not contain provisions on the protection of the right to use by one of the spouses of the house or flat which is rented by another spouse in the case of divorce. According to the principles developed by the CEFL, if a family lease is contracted by one spouse, then both spouses are entitled to it, and one spouse cannot, without the consent of the other, terminate or modify the lease. The landlord is required to notify both spouses of the termination of the lease. In our opinion, similar provisions should be enshrined in the legislation of Ukraine.

According to the principle of $4: 8$, each spouse is obliged to inform the other about their income and debts. The Family Code of Ukraine also needs to be supplemented by a provision that establishes such a duty. 
With respect to the property of each spouse and joint ownership, Chapters 7 and 8 of the Family Code of Ukraine generally comply with the principles of European family law developed by CEFL, except for the attribution of things for professional pursuits to joint joint ownership. When reforming the legislation in order to adapt it to the European principles, provision should be made for assigning things for professional activities to the property of one of the spouses.

Principle 4:21 states that one spouse's debt is his personal debt. Personal debts include debts that: arose before marriage; related to gifts received, inheritance; related to personal property; personal debts; incurred without the necessary consent of the other spouse. Debts that have arisen for the satisfaction of the needs of the family and which are not classified as personal debts are common debts. Personal debts may be recovered from the personal property of one of the spouses. In the event of debt in connection with the commission of an offense or crime, their value may be recovered from half of the joint property if personal property is not sufficient. In our opinion, the same rules should be set in the Family Code of Ukraine.

In August 2019, the Commission on European Family Law promulgated the Fifth Group of Principles on the Ownership, Retention and Succession of Couples in de-facto unions ${ }^{21}$. Based on an analysis of these principles, we have come to the 20 conclusion that, in general, the legal bases for the relationships of persons who are in de-facto family relations are in line with the principles developed by the Commission on European Family Law.

However, it is easy to see the difference in the terminology, the Commission proposes the terms "actual union" (which means two people living together as a couple and having a strong relationship), "qualified factual union" (when the persons are in actual relations at least five years or have a common child) and a "partner" (a person living in an actual union). The Family Code of Ukraine does not use the term "actual marital relations" or "actual marital relations", but only in Article 74 establishes "the right to property of women and men who live in the same family but are not married to each other or to any other marriage." In the scholar

${ }^{21}$ Katharina Boele-Woelki, Frédérique Ferrand, Cristina González-Beilfuss, Maarit Jänterä-Jareborg, Nigel Lowe, Dieter Martiny, Velina Todorova. Principles of European Family Law Regarding Property, Maintenance and Succession Rights of Couples in de facto Unions. 2019. 282 p. 
literature, the terms "actual marriage relations", "actual marriage"22. In legal practice the following term is found: "actual marital relationship". Thus, after the words "one family" in Article 74 of the Family Code of Ukraine, it is worth adding words "in actual union" in order to bring this norm to European standards.

\section{CONCLUSIONS}

The analysis showed that the unification of family law in Europe occurs not only as a result of the adoption of EU Council regulations, ECtHR practices, but also of the activities of the Commission on European Family Law on the unification of principles. The Family Code of Ukraine is generally based on the principles of European family law, which will certainly help to harmonize the legislation of Ukraine and the EU. We are convinced that in the context of the recodification of the Civil Code of Ukraine there is no reason to claim that the Family Code is being decoded. At the same time, the conducted research shows the need for conceptual modernization of the Family Code of Ukraine in the context of European integration processes, including through a number of changes.

\section{SUMMARY}

The study presents the results of the analysis of the impact of the recodification of the Civil Code and the processes of European integration on the development of family law in Ukraine. The author analyzed the views of scholars on the concept of "recodification". The author provided its vision of the stages of recodification. The author concluded that the recodification of the Civil Code may not lead to decodification if the Family code but only to its modernization. It is established that the unification of family law in the EU is due to the adoption of EU Council regulations, ECtHR practices and the activities of the Commission on European Family Law. Based on the analysis of the conformity of the Family Code of Ukraine with the principles of European family law, she suggested specific changes to the legislation. The Family Code of Ukraine is generally based on the principles of European family law, which will certainly help to harmonize the legislation of Ukraine and the EU. We are

22 Сафончик О.I. Деякі питання правового регулювання правовідносин «фактичного подружжя» щодо взаємного утримання. Актуальні проблеми держави і права. 2010. С. 199-204. 
convinced that in the context of the recodification of the Civil Code of Ukraine there is no reason to claim that the Family Code is being decoded. At the same time, the research shows the need for conceptual modernization of the Family Code of Ukraine in the context of European integration processes, including through a number of changes.

\section{REFERENCES}

1. На III Харківському міжнародному юридичному форумі обговорили оновлення цивільного законодавства та необхідність європеїзації приватного права. URL: https://legalforum.nlu.edu.ua/ news/na-iii-kharkivskomu-mizhnarodnomu-iurydychnomu-forumiobhovoryly-onovlennia-tsyvilnoho-zakonodavstva-ta-neobkhidnistievropeizatsii-pryvatnoho-prava/.

2. Музика Л. А. Що є актуальним для сучасного цивільного законодавства України: модернізація, системне оновлення чи рекодифікація? Науковий вісник Львівського державного університету внутрішніх справ. 2015. Вип. 1. С. 145-154.

3. Hondius E.H. Recodification of the Law in the Netherlands: The New Civil Code experience. Netherlands International Law Review. Volume 29, Issue 3. December 1982, pp. 348-367.

4. Довгерт Анатолій. Рекодифікація Цивільного кодексу України: основні чинники і передумови для старту. Право України. 2019. № 1: Національна доктрина приватного права: основні методологічні засади. С. 27-41.

5. Сирко М.В. Цивільний кодекс Франції 1804 року та його вплив на цивільне законодавство країн Свропи (на прикладі Польщі та Румунії). Дисертація на здобуття наукового ступеня кандидата юридичних наук по спец.: 12.00.01 Львів, 2015. 215 с.

6. Про рекодифікацію цивільного права, медіацію та мирову угоду говорили судді КЦС ВС на юридичному форумі у Харкові. URL: https://supreme.court.gov.ua/supreme/pres-centr/news/793713/.

7. Музика Л. Кодифікація та декодифікація: проблемні питання. Jurnalul juridic naţional: teorie și practică. Iunie 2015. C. 52-56.

8. Довгерт Анатолій. Рекодифікація Цивільного кодексу України: основні чинники і передумови для старту. Право України. 2019. № 1: Національна доктрина приватного права: основні методологічні засади. С. 27-41. С. 30.

9. Ілларіонов O. Рекодифікація = декодифікація? URL: https://blog.liga.net/user/aillarionov/article/34014. 
10. Ватрас В.А. Кодифікація новітнього сімейного законодавства: історія та сучасність. Університетські наукові записки, 2016. № 58. С. 35-47.

11. Lhoest B., (2016). The Harmonization of European Family Law: Work in Progress. URL: https://www.peacepalacelibrary.nl/2016/12/theharmonization-of-european-family-law-work-in-progress/.

12. Менджул М. В. Перспективи уніфікації європейського сімейного права. Visegrad Journal on Human Rights. 2019. №. 3. Vol. 1. P. 186. 186-190.

13. Трощенко I. О. Роль Регламенту «Рим II» в уніфікації міжнародного приватного права в ЄС. Держава і право. Юридичні і політичні науки. Випуск 53. 2011. С. 572-576.

14. Ватрас В. А. Проблеми та перспективи кодифікації міжнародного сімейного права України. Міжнародне приватне право. С. 182-186. URL: http://www.univer.km.ua/statti/2.vatras_ v.a._problemy_ta_perspektyvy_kodyfikatsiyi_mizhnarodnoho_ simeynoho_prava_ukrayiny.pdf.

15. Principles of european family law regarding divorce and maintenance between former spouses. URL: http://ceflonline.net/wpcontent/uploads/Principles-English.pdf

16. Principles of european familylaw regarding parental responsibilities. URL: http://ceflonline.net/wp-content/uploads/PrinciplesPR-English.pdf.

17. Principles of european family law regarding property relations between spouses. URL: http://ceflonline.net/wp-content/uploads/ Principles-PRS-English1.pdf.

18. Katharina Boele-Woelki, Frédérique Ferrand, Cristina GonzálezBeilfuss, Maarit Jänterä-Jareborg, Nigel Lowe, Dieter Martiny, Velina Todorova. Principles of European Family Law Regarding Property, Maintenance and Succession Rights of Couples in de facto Unions. 2019. 282 p.

19. Boele-Woelki, K., 2005. The principles of European family law: its aims and prospects. Utrecht Law Review, 1(2), pp. 160-168. DOI: http://doi.org/10.18352/ulr.13.

20. Katharina Boele-Woelki, Frédérique Ferrand, Cristina GonzálezBeilfuss, Maarit Jänterä-Jareborg, Nigel Lowe, Dieter Martiny, Velina Todorova. Principles of European Family Law Regarding Property, Maintenance and Succession Rights of Couples in de facto Unions. 2019. 282 p. 
21. Сафончик O.I. Деякі питання правового регулювання правовідносин «фактичного подружжя» щодо взаємного утримання. Актуальні проблеми держави і права. 2010. С. 199-204.

\section{Information about the author:} Mendzhul M. V.

Candidate of Law Sciences, Associate Professor, Department of Civil Law and Process, Law Faculty, Uzhgorod National University 26, Kapitulna str., Uzhhorod, 88000, Ukraine 